\title{
Ideologi Gender dalam Konstruksi Kurikulum Program Studi di Universitas Negeri Semarang
}

\author{
Yanuari Dwi Puspitarini ${ }^{1}$, Yuli Utanto² \\ Tp11010.yanuaridwi@gmail.com
}

\begin{abstract}
The purpose of this study is to find out how far the gender ideology influence students in choosing courses and how the curriculum construction which is developed by Early Childhood Education and Physical, Sports and Recreation teacher program. This research is a qualitative research with phenomenological approach. This research was conducted at the teacher education of three programs (early childhood education, physical, sports and recreation program) in Universitas Negeri Semarang. The subjects of this research are the students and the lecturers of each study program. The technique of data collection in this research used an interview technique. The results of this research are gender ideology did not directly affect the students in choosing a specific study program, but it begins from the parenting system that is applied by the parents. The structure of curriculum in each study program is arranged in appropriate with the demands in the employment industry.
\end{abstract}

Keywords: Curriculum, Gender Ideology, Study Program

\footnotetext{
1 Teknologi Pendidikan Universitas Negeri Semarang

2 Universitas Negeri Semarang
} 


\section{PENDAHULUAN}

P endidikan merupakan kebutuhan yang pokok bagi masyarakat Indonesia. Lewat pendidikan manusia mampu untuk memajukan kehidupannya, lewat pendidikan pula manusia mampu untuk memajukan bangsanya. Undang-Undang No. 20 Tahun 2003 menyatakan bahwa [endidikan merupakan usaha sadar dan terencana untuk mewujudkan suasana belajar dan proses pembelajaran agar peserta didik secara aktif mengembangkan potensi dirinya untuk memiliki kekuatan spiritual keagamaan, pengendalian diri, kepribadian, kecerdasan, akhlak mulia, serta keterampilan yang diperlukan dirinya, masyarakat, bangsa, dan negara. Pendidikan dilaksanakan pada berbagai jenjang, yaitu jenjang pendidikan dasar (SD/MI/Paket A dan SMP/MTS/Paket B), pendidikan menengah (SMA/SMK/MA/ Paket C), dan pendidikan tinggi (Universitas /Institusi /Sekolah Tinggi/Politeknik/dan lainlain).

Salah satu jenjang pendidikan tinggi adalah universitas. Universitas adalah perguruan tinggi yang menyelenggarakan pendidikan akademik dan dapat menyelenggarakan pendidikan vokasi dalam berbagai rumpun ilmu pengetahuan dan/atau teknologi dan jika memenuhi syarat, universitas dapat menyelenggarakan pendidikan profesi (Peraturan Pemerintah No. 4 tahun 2014 pasal 1 ayat 7). Dalam sebuah universitas, terdapat rumpun ilmu pengetahuan yang dapat dipilih oleh calon mahasiswa baru sesuai dengan minat dan bakatnya. Sesuai dengan Undang-Undang No. 12 tahun 2012 pasal 6 poin (g) menyatakan bahwa kebebasan dalam memilih program studi berdasarkan minat, bakat, dan kemampuan mahasiswa.

Fenomena yang ada dalam pemilihan program studi pada sebuah universitas pada calon mahasiswa baru cenderung memilih program studi sesuai dengan asumsi masyarakat terhadap program studi tertentu (Widodo, 2013). Misalnya pada program studi Pendidikan Guru Pendidikan Anak Usia Dini (PAUD) ditujukan untuk perempuan karena masyarakat berasumsi bahwa Pendidikan Guru PAUD nantinya akan lebih banyak berhubungan dengan anak-anak, dan program studi Pendidikan Jasmani, Kesehatan, dan Rekreasi cocok untuk laki-laki karena kegiatannya lebih pada kegiatan fisik.

Universitas Negeri Semarang merupakan salah satu universitas yang didalamnya terdapat program studi Pendidikan Guru PAUD dan Pendidikan Jasmani, Kesehatan, dan Rekreasi. Pada program studi Pendidikan Guru PAUD dilihat dari beberapa tahun kebelakang jumlah mahasiswanya didominasi oleh perempuan. Berdasarkan hasil wawancara dengan Ketua Jurusan Pendidikan Guru PAUD Universitas Negeri Semarang dan database universitas, angkatan 2012 jumlah mahasiswanya sebanyak 98 orang dengan 96 mahasiswa perempuan dan 2 mahasiswa laki-laki. Ini menunjukkan bahwa mahasiswa baru yang diterima pada program studi tersebut yang berjenis kelamin laki-laki hanya berkisar 2\% dari total mahasiswa baru. Pada angkatan 2013 jumlah mahasiswa Pendidikan Guru PAUD bertambah menjadi 120 mahasiswa dengan jumlah mahasiswa perempuan sebanyak 116 mahasiswa perempuan dan 4 mahasiswa laki-laki atau hanya 3\% dari total mahasiswa baru. Kemudian untuk angkatan 2014 jumlah mahasiswa baru tidak mengalami perubahan yaitu hanya menerima 120 mahasiswa baru dengan jumlah mahasiswa perempuan sebanyak 115 mahasiswa dan 5 mahasiswa lakilaki atau hanya $4 \%$ dari total mahasiswa baru. Meskipun terdapat peningkatan jumlah mahasiswa baru yang berjenis kelamin laki-laki pada program studi tersebut tetapi peminat maupun mahasiswa barunya masih didominasi oleh perempuan.

Pada program studi pendidikan guru jasmani, kesehatan dan rekreasi di-dominasi oleh kaum lakilaki. Data yang diperoleh pada angkatan 2012 jumlah mahasiswanya sebanyak 231 orang dengan jumlah mahasiswa laki-lakinya sebanyak 181 mahasiswa dan 50 mahasiswa perempuan atau hanya $22 \%$ dari total mahasiswa baru. Pada angkatan 2013 jumlah mahasiswanya sebanyak 188 orang dengan jumlah mahasiswa laki-laki 141 mahasiswa dan 47 mahasiswa perempuan atau sebanyak $25 \%$ dari total 
mahasiswa baru. Sedangkan untuk angkatan 2014 program studi pendidikan guru jasmani, kesehatan dan rekreasi menerima mahasiswa baru sebanyak 170 orang dengan jumlah mahasiswa laki-laki 116 mahasiswa dan 54 mahasiswa perempuan atau meningkat menjadi 31\% dari total mahasiswa baru.

Berdasarkan alasan asumsi masyarakat bahwa program studi pendidikan guru paud ditujukan untuk perempuan karena masyarakat berasumsi bahwa pendidikan guru paud nantinya akan lebih banyak berhubungan dengan anak-anak, dan program studi pendidikan jasmani, kesehatan, dan rekreasi cocok untuk laki-laki karena kegiatannya lebih pada kegiatan fisik. Asumsi tersebut tidak lepas dari proses penggenderan didalam keluarga dan masyarakat (Astuti, 2008). Menurut Fakih (2013) gender adalah perbedaan perilaku (behavioral differences) antara laki-laki dan perempuan yang dikonstruksikan secara sosial, yakni perbedaan yang bukan kodrat atau bukan ketentuan Tuhan melainkan diciptakan oleh manusia (laki-laki dan perempuan) melalui proses sosial dan kultural yang panjang. Menurut Oakley (dalam Bhasin, 2001) gender adalah masalah budaya, ia merujuk pada klasisfikasi sosial dari laki-laki dan perempuan menjadi "maskulin" dan "feminin". Jadi perbedaan dalam pembentukan identitas maskulin dan feminin akan menimbulkan ketidakadilan antara laki-laki dan perempuan yang sering disebut dengan ketidakadilan gender atau ketimpangan gender.

Ketidakadilan gender tidak hanya ada di masyarakat, tetapi merambah pada dunia pendidikan. Salah satu contoh bias gender dalam pendidikan dapat dilihat pada perumusan kurikulum dan rendahnya kualitas pendidikan. Kurikulum merupakan sejumlah mata pelajaran (subject) yang harus ditempuh oleh seorang mahasiswa dari awal sampai akhir program pelajaran untuk memperoleh penghargaan dalam bentuk ijazah. Berdasarkan pengertian diatas, dalam kurikulum terkandung dua hal pokok, yaitu: (1) adanya mata pelajaran yang harus ditempuh oleh siswa, dan (2) tujuan utamanya yaitu untuk memperoleh ijazah (Ruhimat et al, 2013).

Pengertian kurikulum menurut Undang-Undang No. 20 Tahun 2003 tentang Sistem Pendidikan Nasional dalam Bab I pasal 1 poin 19 adalah seperangkat rencana dan pengaturan mengenai tujuan, isi, dan bahan pelajaran serta cara yang digunakan sebagai pedoman penyelenggaraan kegiatan pembelajaran untuk mencapai tujuan pendidikan tertentu. Dari pengertian diatas dimaksudkan bahwa dalam kurikulum memuat tujuan yang akan dicapai dengan jelas setelah kurikulum tersebut dilaksanakan, memuat konten kurikulum yang sesuai dengan tujuan, memuat bahan pelajaran yang akan disampaikan dalam pembelajaran, serta pengaturan-pengaturan yang digunakan dalam menyelenggarakan kegiatan pembelajaran. Jadi kurikulum adalah semua rencana dan pengaturan yang tertulis maupun tidak tertulis mengenai penyelenggaraan proses pembelajaran untuk mencapai tujuan pendidikan yang berupa ijazah.

Realitas yang ada, dalam kurikulum pendidikan (agama ataupun umum) masih terdapat banyak hal yang menonjolkan laki-laki berada pada sektor publik sementara perempuan berada pada sektor domestik (Ampera, 2012). Menurut Suryadi dan Idris (2004) terdapat faktor yang mempengaruhi kesenjangan gender berkaitan dengan kurikulum dan proses pembelajaran, yaitu: (1) partisipasi perempuan dalam proses pengambilan keputusan pendidikan sangat rendah ka-rena akses mereka juga rendah dalam menempati jabatan-jabatan birokrasi pemegang kebijaksanaan, (2) laki-laki lebih dominan dalam mempengaruhi isi kurikulum sehingga proses pembelajaran cenderung lebih bias laki-laki (male bias), (3) isi buku pelajaran yang membahas status perempuan dalam masyarakat akan banyak memberikan pengaruh terhadap kesenjangan gender dalam proses pendidikan.

Berdasarkan uraian diatas, peneliti tertarik untuk melakukan penelitian dengan bahan kajian adanya mayoritas gender tertentu dalam suatu program studi dan bagaimana struktur kurikulum yang diterapkan pada beberapa program studi sehingga identik dengan gender tertentu.

Tujuan dari penelitian ini adalah (1) untuk mengetahui sejauh mana ideologi gender mempengaruhi mahasiswa dalam memilih program studi (2) untuk mengetahui bagaimana konstruksi kurikulum yang 
dikembangkan pada program studi pendidikan guru paud dan pendidikan jasmani kesehatan dan rekreasi di Universitas Negeri Semarang.

\section{METODE PENELITIAN}

Metode yang digunakan dalam penelitian ini adalah kualitatif dengan pendekatan penelitian fenomenologi. Metode penelitian kualitatif adalah metode penelitian yang berlandaskan pada filsafat pospositivisme, digunakan untuk meneliti pada kondisi obyek alamiah, dimana peneliti adalah sebagai instrument kunci, pengambilan sampel sumber data dilakukan secara purposive dan snowball, teknik pengumpulan dengan triangulasi (gabungan), analisis data bersifat induktif/kualitatif, dan hasil penelitian kualitatif lebih menekankan makna daripada generalisasi (Sugiyono, 2012). Menurut Cokroaminoto (2011) penelitian fenomenologi mencoba menjelaskan atau mengungkap makna konsep atau fenomena pengalaman yang didasari oleh kesadaran yang terjadi pada beberapa individu.

Tempat penelitian ini dilakukan di Universitas Negeri Semarang pada program studi Pendidikan Guru PAUD dan Pendidikan Jasmani, Kesehatan, dan Rekreasi, dengan subyek penelitian mahasiswa dan dosen pada masing-masing program studi. Teknik pengumpulan data yang digunakan yaitu: (1) observasi dilakukan pada lingkungan kampus, (2) wawancara kepada mahasiswa dan dosen masingmasing program studi, dan (3) dokumentasi berupa struktur kurikulum pada masing-masing program studi dan foto kegiatan wawancara.

Analisis data yang digunakan dalam penelitian ini adalah interactive model) yang terdiri dari: (1) data collection (pengumpulan data), yaitu kegiatan mencari dan mengumpulkan berbagai macam jenis dan bentuk data yang ada dilapangan. Data tersebut dapat berupa hasil dari kegiatan wawancara maupun hasil dokumentasi. (2) Data reduction (reduksi data), yaitu kegiatan merangkum, memilih data-data yang pokok dan memfokuskan pada hal-hal yang dianggap penting, serta membuang yang tidak diperlukan, Mereduksi data merupakan bentuk analisis menggolongkan data, memfokuskan dan membuang data yang tidak diperlukan. (3) Data display (penyajian data), penyajian data dalam penelitian kualitatif dapat menggunakan uraian singkat, bagan, hubungan antara kategori, flowchart, dan sejanisnya. Kegiatan mendisplaykan data akan memudahkan dalam memahami apa yang terjadi dan merencanakan kerja selanjutnya berdasarkan apa yang telah dipahami. (4) Cunclosing Drawing / Verification, data yang telah didapat dalam penelitian kemudian ditarik kesimpulannya.

Keabsahan data dalam penelitian kuantitatif disebut validitas data. Dalam penelitian ini untuk memeriksa keabsahan atau validitas data yang dilaporkan, peneliti menggunakan teknik triangulasi. Teknik triangulasi pada penelitian ini menggunakan teknik teriangulasi sumber. Triangulasi sumber digunakan untuk menguji kredibilitas data yang telah didapatkan melalui beberapa sumber.

\section{HASIL DAN PEMBAHASAN}

Penelitian ini dilakukan selama 3 bulan yaitu pada bulan Agustus sampai bulan Oktober 2015. Pengumpulan data yang diperoleh dengan teknik observasi, wawancara dan dokumentasi. Objek penelitian adalah mahasiswa dan dosen program studi pendidikan guru paud dan pendidikan jasmani, kesehatan, dan rekreasi.

Program studi Pendidikan Guru PAUD merupakan salah satu program studi yang ada di Fakultas IImu Pendidikan yang beralamat di Kampus Sekaran gedung A3 lantai 1 Fakultas IImu Pendidikan. Program studi Pendidikan Guru PAUD merupakan satu-satunya program studi pada jurusan Pendidikan Guru PAUD yang biasa disebut dengan PG-PAUD. Jurusan PG-PAUD FIP UNNES menyelenggarakan 
pendidikan akademik dan profesi untuk menghasilkan sarjana pendidikan di bidang pendidikan anak usia dini yang mengembangkan kajian, penelitian, pelatihan di bidang pendidikan anak usia dini serta menyelenggarakan bimbingan, pendampingan, advokasi, dan bantuan profesional kepada masyarakat di bidang pendidikan anak usia dini.

Program studi Pendidikan Jasmani, Kesehatan dan Rekreasi merupakan salah satu program studi yang ada di Fakultas IImu Keolahragaan yang beralamat di Kampus Sekaran gedung F1 lantai 2 Fakultas IImu Keolahragaan. Prodi Pendidikan Jasmani Kesehatan dan Rekreasi adalah salah satu dari empat prodi di Fakultas IImu Keolahragaan. Prodi ini menyelenggarakan Pendidikan Jasmani Kesehatan dan Rekreasi dengan tujuan menghasilkan lulusan dalam bidang pengajaran Pendidikan Jasmani, Olahraga dan Kesehatan dilingkungan Satuan Pendidikan dengan kualifikasi sarjana pendidikan (S1) yang unggul, profesional, terampil, dan peka terhadap kelestarian lingkungan sosial masyarakat.

\section{Ideologi Gender dalam Pemilihan Program Studi}

Gender merupakan hal yang membingungkan bagi sebagian orang awam, karena mereka menganggap gender sama dengan jenis kelamin. Pada kenyataanya, gender berbeda dengan jenis kelamin. Jenis kelamin adalah perbedaan antar laki-laki dan perempuan yang diidentifikasikan menurut bentuk biologisnya, sedangkan gender merupakan perbedaan antara sifat yang melekat pada laki-laki maupun perempuan yang terbentuk oleh situasi sosial maupun kultural.

Identifikasi gender atau penggenderan sudah terjadi sejak zaman dahulu. Pada zaman dahulu penggenderan sangat memojokkan kaum perempuan. Bahkan para orang tua zaman dahulu menganut paham perempuan itu pekerjaanya "masak, macak, lan manak" (dalam bahasa jawa). Masak artinya sebagai perempuan dia harus bisa mengurus rumah tangganya seperti memasak, mengurus anak, mengurus rumah dan semua hal yang berkaitan dengan kebersihan rumah. Macak artinya sebagai perempuan dia harus pintar berdandan untuk menyenangkan suami agar suami betah dirumah. Sedangkan manak artinya pekerjaan perempuan selanjutnya adalah mengandung dan melahirkan anak agar keturunan mereka terus berlanjut. Dari paham tersebut menyebabkan wilayah kerja perempuan sempit, yaitu hanya sekitar rumah saja.

Berbeda dengan perempuan, kaum laki-laki mendapatkan tempat yang istimewa. Laki-laki selalu dinomor satukan dan mendapatkan kedudukan yang tinggi. Hal tersebut didasarkan pada posisi laki-laki yang pada saat itu menjadi kepala keluarga dan menjadi tulang punggung dalam mencari nafkah untuk keluarga. Oleh sebab itu dari kecil, kaum laki-laki sudah dipersiapkan untuk menjadi tulang punggung keluarga dengan mengasuh dan mendidik mereka dengan keras. Atas dasar kaum laki-laki pada nantinya akan menjadi kepala keluarga dan tulang punggung keluarga pendidikan pada masa itu juga sebagian besar ditujukan untuk laki-laki. Walaupun seorang perempuan lahir pada keluarga yang berada pada saat itu, tetapi kesempatan pendidikan belum tentu akan diberiakan oleh orang tua.

Identifikasi gender tidak hanya terjadi dalam lingkungan keluarga dan masyarakat, tetapi juga dalam lingkungan pendidikan. Pada lingkungan keluarga, dimulai dari pola asuh yang diterapkan orang tua terhadap anaknya. Pola asuh anak pada setiap keluarga pasti berbeda-beda. Anak laki-laki akan diperlakukan tegas karena laki-laki dianggap keras dan rasional, sedangkan anak perempuan akan diperlakukan lemah-lembut dan lebih fleksibel karena perempuan dianggap lebih sensitif dan irrasional. Pola asuh tersebutlah yang akan berpengaruh terhadap karekter anak. Seperti diungkapkan Hurlock dalam Anisah (2011) bahwa "Sikap orang tua mempengaruhi cara mereka memperlakukan anak, perlakuan mereka terhadap anak sebaliknya mempengaruhi sikap anak terhadap mereka dan perilaku mereka...". 
Dari pernyataan berikut menjelaskan bahwa sikap orang tua dalam mengasuh anak memiliki kecenderungan yang lebih dominan kepada pola asuh tertentu, apakah akan berdampak positif atau negatif terhadap perkembangan anak.

Karakter yang didapat dari pola asuh yang diterapkan orang tua akan terbawa oleh anak pada pergaulannya dilingkungan masyarakat. Karakter tersebut juga akan dibawa anak sampai dia besar dan pada akhirnya akan memilih pendidikan (program studi) yang sesuai dengan karakter mereka. Dari hasil penelitian yang dilakukan pada program studi Pendidikan Guru PAUD dan Pendidikan Jasmani, Kesehatan, dan Rekreasi pola asuh memang mempengaruhi karakter meraka tetapi dalam menentukan program studi mereka tidak dipengaruhi oleh orang tua. Mereka memilih program studi sesuai dengan keinginan mereka, orang tua hanya mendukung dan memfasilitasi.

Pola asuh ternyata juga diduga mempengaruhi pilihan dan persepsi tentang Pendidikan termasuk pilihan program studi. Berikut ini merupakan analisis yang disarikan dari persepsi mahasiswa tentang program studi:

Pertama, alasan memilih program studi. Pada program studi Pendidikan Guru PAUD dalam pemilihan program studi sebagian besar mahasiswa Pendidikan Guru PAUD memilih program studi tersebut atas alasan menyukai anak-anak dan kedepannya ingin mengabdikan diri pada dunia anakanak. Mereka juga ingin mempelajari bagaimana menjadi pendidik yang baik, karena sebagian besar mahsiswa Pendidikan Guru PAUD adalah wanita yang mereka juga akan menjadi seorang ibu. Sedangkan pada program studi Pendidikan Jasmani, Kesehatan, dan Rekreasi sebagian besar mahasiswa Pendidikan Jasmani, Kesehatan, dan Rekreasi memilih program studi tersebut dengan alasan bahwa program studi tersebut sesuai dengan keahlian mereka dan karena mereka suka berolahraga. Seperti penuturan FA salah satu narasumber yang merupakan mahasiswa Pendidikan Guru PAUD, menyatakan bahwa:

"Alasan saya memilih program studi PG-PAUD karena menurut saya potensi didalam diri saya lebih mengacu ke jurusan PG-PAUD dan karena saya ingin menjadi pendidik yang bisa membangun dan membentuk karakter anak bangsa."

Dalam pemilihan program studi ada banyak alasan yang mendasari pemilihan suatu program studi dan mayoritas mereka memilih berdasarkan pilihan hati tanpa memeperhatikan aspek gender. Seperti penuturan mahasiswa PG-PAUD, SN yang menyatakan:

"Perbedaan gender tidak mempengaruhi saya dalam memilih program studi PG-PAUD, alasan saya memilih program studi PG-PAUD karena Saya suka dengan dunia anak-anak yang menyenangkan, bahkan cara belajarnyapun tidak seperti orang dewasa belajar. Anak-anak belajar melalui bermain, itu yang membuat keseruan tersendiri dalam mempelajari dunia anak".

Banyak juga mahasiswa yang memperhatikan karir dan kegemaran dalam pemilihan program studi. Seperti penuturan DS, mahasiswa PJKR menyatakan:

"Alasan saya memilih program studi PJKR karena saya suka berolahraga dan saya tidak terlalu suka berlama-lama duduk dibangku ruang kuliah. Setelah kuliah saya ingin menjadi guru olahraga"

Kedua, pandangan terhadap program studi. Pandangan terhadap program studi Pendidikan Guru PAUD adalah program studi yang mayoritas mahasiswanya adalah perempuan. Perempuan yang selalu diidentikkan dengan dunia anak, karena dalam ksehidupan sehari-hari perempuanlah yang menjalankan tugas menjaga dan mengasuh anak dirumah. Sedangkan Pandangan terhadap program studi Pendidikan Jasmani, Kesehatan, dan Rekreasi adalah program studi yang mayoritas mahasiswanya adalah laki-laki. 
Laki-laki diidentikkan dengan orang yang kuat dan cocok untuk melakukan aktivitas olahraga. Seperti penuturan UL salah satu mahasiswa Pendidikan Jasmani, Kesehatan, dan Rekreasi menyatakan bahwa:

"PG-PAUD dipilih oleh mayoritas perempuan karena nantinya akan banyak berhubungan dengan anak-anak yang memerlukan kesabaran lebih, sedangkan PJKR identik dengan laki-laki karena dalam olahraga diperlukan fisik dan stamina yang kuat."

Namun mahasiswa juga menyadari bahwa dalam pandangan masyarakat luas ada beberapa program studi (termasuk program studi mereka) yang dianggap sebagai program studi yang identik dengan gender tertentu, salah satunya Pendidikan Guru PAUD. Meskipun demikian mereka berupaya menampik pemahaman yang mereka anggap salah tersebut. Ketika hal ini ditanyakan kepada beberapa mahasiswa Pendidikan Guru PAUD, SA menyatakan bahwa:

"Ketika ada pendapat yang menyatakan ada program studi yang di identikkan dengan gender tertentu menurut saya, semua program studi itu dipilih sesuai dengan bakat dan kemampuan seseorang. Jadi pemilihan program studi tidak disesuaikan dengan gender tertentu"

Ketiga, pola asuh keluarga. Pada mahasiswa program studi Pendidikan Guru PAUD menyatakan bahwa pola asuh orang tua kepada anak dirumah cenderung keras (dalam arti tegas) tetapi tetap mengutamakan kasih sayang (Wijanarko \& Setiawati, 2016).. Ketegasan itu dimaksudkan untuk mendidik anak-anak mereka agar lebih disiplin dan tidak bergantung pada orang lain. Sedangkan pada program mahasiswa studi Pendidikan Jas-mani, Kesehatan, dan Rekreasi menyatakan bahwa pola asuh orang tua yang di terapkan pada anak-anaknya yaitu keras tetapi tetap menerapkan asas demokrasi, sehingga walaupun mereka dididik dengan keras supaya mereka tidak lemah dan demokratis karena pada umumnya laki-laki tidak suka diatur. Seperti penuturan SA salah satu mahasiswa Pendidikan Guru PAUD menyatakan bahwa:

"Orang tua saya mendidik saya dengan cara otoriter. Saya dididik dengan keras oleh orang tua saya, tetapi saya juga tidak kehilangan kasih sayang dari mereka. Orang tua saya mendidik saya dengan keras agar saya lebih disiplin dan mandiri dalam kehidupan yang saya jalani."

Keempat, pandangan tentang fenomena bias gender. Pada program studi Pendidikan Guru PAUD fenomena bias gender sudah muncul di masyarakat sejak lama. Praktek ketidakadilan gender tersebut juga tidak hanya dilingkungan keluarga tetapi sudah berkembang sampai lingkungan masyarakat. Misalnya ketika anak laki-laki bermain, jarang sekali mereka bermain dengan anak perempuan terutama untuk permainan-permainan yang dianggap permainan keras untuk anak laki-laki. Perempuan dipandang tidak pantas dan tidak bisa bermain. egitu pula sebaliknya ketika anak laki-laki yang bermain dengan perempuan akan dianggap cengeng atau lemah. Sedangkan pada program studi Pendidikan Jasmani, Kesehatan, dan Rekreasi fenomena bias gender merupakan hal yang sudah biasa dan umum di masyarakat. Fenomena bias gender juga ada di program studi Pendidikan Jasmani, Kesehatan, dan Rekreasi. Biasanya kalau kaum minoritas yang ada dalam lingkungan mayoritas akan dikucilkan. Pada program studi Pendidikan Jasmani, Kesehatan, dan Rekreasi perempuan dituntut untuk bias melakukan kegiatan yang lebih keras dibandingkan dengan kegiatan perempuan pada umumnya. Seperti penuturan AR salah satu mahasiswa Pendidikan Jasmani, Kesehatan, dan Rekreasi menyatakan bahwa:

"Hal-hal mengenai gender misalnya dikampung saya selama ini tidak ada perempuan yang menjadi kepala desa. Bahkan sebagai calonpun tidak ada. Perbedaan gender mempengaruhi saya dalam kehidupan sehari-hari, misalnya biasanya pekerjaan-pekerjaan berat dilakukan oleh lakilaki jadi nggak tega kalau melihat perempuan yang mengerjakannya." 
Kelima, perubahan cara pandang terhadap fenomena bias gender. Pada program studi Pendidikan Guru PAUD menyatakan setelah adanya gerakan kesetaraan gender setiap orang dapat menempati posisi yang mereka inginkan tanpa adanya gunjingan dari orang lain (Saputra \& Sukadana, 2018). Setiap orang dapat memilih apa yang mereka sukai, tidak peduli cenderung ke feminim atau maskulin. Sedangkan pada program studi Pendidikan Jasmani, Kesehatan, dan Rekreasi menyatakan setelah adanya gerakan kesetaraan gender semua orang dapat diperlakukan sama, tanpa memandang jenis kelamin dan sifatnya. Semua orang dapat memilih berbagai macam profesi dalam bekerja, tanpa memandang bahwa profesi itu identik dengan perempuan maupun laki-laki dan bekerja secara profesional. Seperti penuturan UL salah satu mahasiswa Pendidikan Jasmani, kesehatan, dan Rekreasi menyatakan bahwa:

"Adanya gerakan kesetaraan gender tidak ada masalah, misalnya saja ketika ada pada tuntutan profesi. Dalam pembelajaran olahraga perempuan juga dituntut untuk bias melakukan seperti halnya laki-laki."

\section{Konstruksi Kurikulum Program Studi}

Pendidikan merupakan wadah bagi masyarakat untuk menimba ilmu pengetahuan. Lewat pendidikan, ilmu pengetahuan menjadi lebih mudah untuk disampaikan kepada masyarakat. Dalam sistem pendidikan, penyampaian ilmu pengetahuan tidak seta merta diberikan kepada siswa. Pendidikan mempunyai sistem yang mengatur suatu lembaga pendidikan agar berjalan sesuai dengan tujuan yang akan dicapai. Sistem tersebut disebut dengan kurikulum. Penyusunan kurikulum tidak terlepas dari isu gender dan ketidakadilan gender dalam masyarakat. Ketidakadilan gender juga merambah pada sektor pendidikan yang mengakibatkan adanya bias gender. Sesuai dengan (Ampera, 2012) salah satu contoh bias gender dalam pendidikan dapat dilihat pada perumusan kurikulum dan juga rendahnya kualitas pendidikan. Realitas yang ada, dalam kurikulum pendidikan (agama ataupun umum) masih terdapat banyak hal yang menonjolkan laki-laki berada pada sektor publik sementara perempuan berada pada sektor domestik.

Kurikulum terus berkembang sesuai dengan kemajuan zaman dan kebutuhan masyarakat pada akhir pendidikan atau kebutuhan dunia kerja. Dengan adanya isu gender kurikulum terus menyesuaikan, sehingga tidak akan muncul bias gender didalamnya. Selain tidak bias gender kurikulum juga disusun sesuai dengan kebutuhan dan tuntutan dunia kerja, sehingga lulusan dari program studi tersebut sudah siap menghadapi tantangan dunia kerja yang sesungguhnya. Struktur kurikulum pada masing-masing program studi bersifat universal, jadi tidak ada unsur condong pada gender tertentu. Dalam proses penerimaan mahasiswa baru pada masing-masing program studi tidak mempunyai standar tertentu yang menjadi syarat masuk. Pada jalur undangan penerimaan mahasiswa baru ditentukan oleh nilai yang telah didapan ketika jenjang SMA/SMK/MA. Pada jalur tertulis penerimaan mahasiswa baru ditentukan oleh nilai yang didapat ketika tes tertulis. Kecuali pada program studi Pendidikan Jasmani, Kesehatan, dan Rekreasi calon mahasiswa baru harus memperliharkan skill melalui video keterampilan, piagam penghargaan dan sebagainnya.

Struktur kurikulum terlihat dapat dibaca dari visi dan misi program studi dan dari hasil penelusuran penulis, kedua program studi diatas sangat tepat menyusun visinya dalam narasi yang general tanpa memasukan unsur gender didalamnya sehingga ditarik kesimpulan bahwa program studi tersebut bebas dari bias gender.

Dalam proses pembelajaran tidak ada perlakuan berbeda antara mahasiswa laki-laki dan perempuan. Semua mahasiswa diperlakukan sama dalam proses pembelajaran teori maupun praktik. Pada program studi Pendidikan Jasmani, Kesehatan, dan Rekreasi yang mata kuliahnya lebih banyak 
pada aktifitas fisik, mahasiswa perempuan diperlakukan sama dengan mahasiswa laki-laki meskipun tidak sama persis karena kemampuan fisik laki-laki dan perempuan berbeda. Pada kegiatan praktik semua mahasiswa berbaur menjadi satu agar tidak timbul kesenjangan antar mahasiswa.

Mata kuliah pada masing-masing program studi disesuaikan dengan rumpun ilmunya masingmasing. Pada program studi Pendidikan Guru PAUD mata kuliahnya meliputi konse-konsep ilmu pendidikan anak usia dini, seperti mata kuliah Pengantar Pendidikan Anak Usia Dini, Pengmbangan Media Anak Usia Dini, dan lain-lain. Lulusan dari program studi Pendidikan Guru PAUD pun tidak melulu agar menjadi guru PAUD, tetapi ada beberapa profil lulusan yang dapat dipilih oleh mahasiswa seperti Pendidik AUD, Pengembang Media AUD, Peneliti PAUD, dan Pengeleola Lembaga PAUD. Mata kuliah yang menjadi cerminan kompetensi inti lulusan tersebut semua mengakomodasi pertimbangan gender dan pengembanganya. Artinya mata kuliah tersebut didesain untuk dapat digunakan dan diikuti oleh semua gender (laki-laki dan perempuan)

Hal demikian juga terjadi pada program studi Pendidikan Jasmani, Kesehatan, dan Rekreasi mata kuliahnya meliputi mata kuliah keahlian berkarya yang mencirikan program studi Pendidikan Jasmani, Kesehatan, dan Rekreasi seperti Pendidikan Kesehatan Sekolah, IImu Gizi Olahraga, dan lain-lain. Lulusan dari program studi Pendidikan Jasmani, Kesehatan, dan Rekreasi yang utama adalah menjadi Guru Pendidikan Jasmani, Kesehatan, dan Rekreasi, Tutor Pendidikan Jasmani, Kesehatan, dan Rekreasi, dan lain-lain. Dari desain lulusan dan mata kuliah yang mencerminkan kukhususan program studi menunjukan bahwa pertimbangan gender sudah dimasukan. Profesi yang menjadi luaran program studi bias diisi semua gender. Demikian juga mata kuliah pada program studi tersebut didesain untuk dapat digunakan dan diikuti oleh semua gender (laki-laki dan perempuan)

\section{KESIMPULAN}

Berdasarkan hasil penelitian yang telah dilakukan, ideologi gender berpengaruh terhadap semua sendi kehidupan. Ideologi gender tidak langsung berpengaruh terhadap alasan mahasiswa Pendidikan Guru PAUD dan Pendidkan Jasmani, Kesehatan, dan Rekreasi dalam memilih program studi. Pengaruh adanya ideologi gender lebih dirasakan dalam kehidupan sehari-hari dan dalam pola asuh yang diterapkan orang tua. Pola asuh orang tua akan mempengaruhi bagaimana seorang anak akan tumbuh dan berkembang. Pola asuh orang tua juga akan mempengaruhi karakter anak, bagaimana dia akan berperilaku, berfikir, dan pada akhirnya mengambil keputusan. Mereka memilih program studi sesuai dengan keinginan mereka, orang tua hanya mendukung dan memfasilitasi. Sedangkan Konstruksi kurikulum pada program studi Pendidikan Guru PAUD dan Pendidikan Jasmani, Kesehatan, dan Rekreasi disusun sesuai dengan kebutuhan dan tuntutan dunia kerja. Seperti program studi Pendidikan Guru PAUD yang mempelajari bidang pendidikan anak usia dini yang diidentik dengan perempuan karena berhubungan dengan anak-anak. Sedangkan program studi Pendidikan Jasmani, Kesehatan, dan Rekreasi yang mempelajari bidang olahraga sehingga dididentikkan dengan laki-laki karena aktifitasnya yang membutuhkan tenaga yang lebih besar.

\section{UCAPAN TERIMA KASIH}

Penulis mengucapkan terima kasih kepada: Drs. Sugeng Purwanto, M. Pd., selaku Ketua Jurusan Kurikulum dan Teknologi Pendidikan, Dr. Yuli Utanto S.Pd., M.Si., selaku Dosen Pembimbing yang telah memberikan bimbingan dan arahan dalam penyusunan skripsi ini, Edi Waluyo, M.Pd., selaku Ketua Program Studi Pendidikan Guru PAUD, Drs. Mugiyo Hartono, M.Pd., selaku Ketua Program Studi Pendidikan Jasmani, Kesehatan, dan Rekreasi yang telah memberikan ijin penelitian, serta mahasiswa dan dosen program studi Pendidikan Guru PAUD dan Pendidikan Jasmani, Kesehatan, dan Rekreasi yang bersedia membantu dalam pelaksanaan penelitian. 


\section{DAFTAR PUSTAKA}

Anisah, A. S. (2011). Pola Asuh Orang Tua dan Implikasinya Terhadap Pembentukan Karakter Anak. Jurnal Pendidikan Universitas Garut, 5 (1), 70-84.

Ampera, D. (2012). Kajian Kesetaraan Gender Dalam Pendidikan di Sekolah Mitra PPL PGSD. Jurnal Tabularasa Pps Unimed 9(2)l, 229-246.

Astuti, T. M. P. (2008). Konstruksi Gender dalam Realitas Sosial. Semarang: UNNES Press.

Bhasin, K. (2001). Memahami Gender. Jakarta: Teplok Press.

Cokroaminoto. (2011). Jenis-jenis Penelitian Kualitatif. Tersedia di http://www.menulisproposalpenelitian.com/2011/01/jenis-jenis-penelitian-kualitatif.html [diakses pada 24-07-2015].

Fakih, M. (2013). Analisis Gender dan Transformasi Sosial. Yogyakarta: Pustaka Pelajar.

Ruhimat, et al. (2013). Kurikulum dan Pembelajaran. Jakarta: Rajawali Pers.

Saputra, A. \& Sukadana, I. W., (2018). Diskriminasi Antara Anak Laki-Laki Dan Perempuan: Studi Kasus Pada Pengeluaran Rumah Tangga di Indonesia dengan Menggunakan Data IFL. E-Jurnal Ekonomi Pembangunan Universitas Udayana,7(5), 868-895

Sugiyono. (2012). Metode Penelitian Pendidikan (Pendekatan Kuantitatif, Kualitatif, dan R\&D). Bandung: Alfabeta.

Suryadi, A \& Idris. (2004). Kesetaraan Gender Dalam Bidang Pendidikan. Bandung: PT Genesindo

Widodo, A. A. (2013). Partisipasi Masyarakat Dalam Implementasi Kebijakan Wajib Belajar 9 Tahun Di Kecamatan Kaligondang Kabupaten Purbalingga. Spektrum Analisis Kebijakan Pendidikan, 2 (2), $22-45$

Wijanarko, J. \& Setiawati, E. (2016). Ayah Ibu Baik Parenting Era Digital: Pengaruh Gadget pada Perilaku dan Kemampuan Anak Menjadi Orang Tua Bijak di Era Digital. Jakarta: Keluarga Indonesia Bahagia Bumi Bintaro Permai 